\title{
Preliminary Taxonomic Study of Members of the Order Actinomycetales That Produce Antibiotics of the Aureolic Acid Group
}

\author{
JERRY D. SKARBEK ${ }^{1}$ AND LYNN R. BRADY ${ }^{2}$ \\ Department of Pharmacognosy, School of Pharmacy, University of Maryland, Baltimore, Maryland 21201, ${ }^{1}$ \\ and Department of Pharmaceutical Sciences, School of Pharmacy, University of Washington, Seattle, \\ Washington $98195^{2}$
}

\begin{abstract}
Fifteen strains of Actinomycetales alleged to produce antibiotics belonging to the aureolic acid group, some of which are useful as antitumor agents, were compared taxonomically with Streptomyces cavourensis subsp. washingtonensis strain AUW-83, a strain which produces chromomycin antibiotics. Of these strains, Streptomyces aburaviensis ATCC 23869, Streptomyces minutiscleroticus ATCC 17757, and $S$. cavourensis subsp. washingtonensis strain AUW-83 are type strains. None of the strains were regarded as similar enough to strain AUW83 to be placed in S. cavourensis subsp. washingtonensis. Bristol's Streptomyces sp. C-14795, a chromomycin-producing strain which has not been previously reported in the literature, and $S$. aburaviensis ATCC 23869 appear to be different strains of the same species; the same is true of Streptomyces griseus no. 7 and Streptomyces sp. KCC S-1081 and of Streptomyces argillaceus F.D. no. 6590 and Streptomyces sp. M-198. However, to establish the identities and taxonomic relationships of these 15 strains, further studies involving direct comparisons with type and/or neotype strains of closely related nomenspecies will be required.
\end{abstract}

The aureolic acid group of antibiotics produced by members of the order Actinomycetales consists of aromatic glycosides of three recognized structural types: the aureolic acid, the chromomycin, and the olivomycin types (1). One member of each type, namely, mithramycin, chromomycin $\mathrm{A}_{3}$, and olivomycin $\mathrm{A}$, respectively, is of clinical usefulness as an antitumor agent, and these have recently been the subject of a review (25). Since 1953, the occurrence of over 20 antibiotic substances belonging to this group has been recorded. A chronological listing of these antibiotics, along with the strains which produce them, has been presented in our previous report describing the fermentation, isolation, and identification of chromomycin $\mathbf{A}_{3}$ from Streptomyces cavourensis subsp. washingtonensis strain AUW-83 (23).

Reported here are the results of a direct taxonomic comparison of strain AUW-83 with 15 strains of Actinomycetales that have been claimed to produce antibiotics belonging to the aureolic acid group. The main purpose of this report is to present the taxonomic features of $S$. cavourensis subsp. washingtonensis strain AUW-83 that distinguish it from the other 15 study strains.

(This manuscript was abstracted in part from a dissertation submitted to the Graduate School of the University of Washington by J. D. Skar- bek in partial fulfillment of the requirements for the degree of Doctor of Philosophy.)

\section{MATERIALS AND METHODS}

Bacterial strains. A list of the strains used in this study is presented in Table 1. Cultures of these strains were acquired in 1972 and 1973. Strains Lilly M518903, Gruppo Lepetit L.A. 7017, and INA 3014 were maintained in the sporulating state on Difco ISP medium 4 (inorganic salts-starch agar); all remaining strains were maintained on Difco ISP medium 2 (yeast-malt extract agar).

ISP methods. Procedures recommended by collaborators of the International Streptomyces Project (ISP) (20) were employed for determinations of spore chain morphology, spore characteristics, aerial mass color, color of substrate mycelium and soluble pigments, melanoid pigmentation, and carbon utilization. ISP media $1,2,3,4,5,6,7$, and 9 were obtained from Difco Laboratories.

Additional materials and methods. The procedure of Gyllenberg and Thelestam (6) was employed for the spectrophotometric evaluation of sporulating cultures for polyenes. Spores and aerial mycelia from cultures grown on both yeast-malt extract agar and oatmeal agar in screw-capped tubes were separately suspended with a loop in $10 \mathrm{ml}$ of ethanol USP, and the suspensions were immediately decanted into test tubes. The suspensions were allowed to remain at room temperature for about $1 \mathrm{~h}$ and were then centrifuged at $10,000 \mathrm{rpm}$ for $10 \mathrm{~min}$. The supernatants were carefully decanted, and the spectra of these ethanolic extracts were recorded with a Beckman model 
TABLE 1. List of strains used

\begin{tabular}{l}
\hline Specific name of strain as received \\
Actinomyces atroolivaceus (4) \\
A. globisporus subsp. flavofuscus \\
$(28)$
\end{tabular}
(28)

A. nigrificans (28)

A. variabilis (28)

Streptomyces aburaviensis Nishimura et al. $(13,21)$

\section{S. argillaceus $^{e}$}

S. cavourensis subsp. washingtonensis Skarbek and Brady

S. griseus $^{h}$

S. lavendulae

S. minutiscleroticus (Thirumalachar) Pridham $(16,22,26)$

S. plicatus ${ }^{e}$

Streptomyces sp. (18)

Streptomyces sp.

Streptomyces sp.

Streptomyces sp. (19)

Streptomyces sp.

Strain designation

INA $11294^{a}$

INA $11296^{b}$

INA $3014^{c}$

INA $232^{d}$

$\mathrm{S}-66=\mathrm{ATCC}$ 23869 (Type strain)

F. D. no. $6590^{f}$

AUW-83 =
ATCC 27732
(Type strain) $^{g}$
No. $7=$ ATCC $^{\circ}$
13273
M5-18903
HACC $147=$
ATCC 17757
(Type strain)
F. D. no. 13756
C-1228

KCC S- $1081^{m}$

L. A. 7017

NA $364-\mathrm{A}^{2} 4^{n}=$ M-198
Source

G. F. Gause, Institute of New Antibiotics, Moscow, U.S.S.R.

G. F. Gause, Institute of New Antibiotics, Moscow, U.S.S.R.

G. F. Gause, Institute of New Antibiotics, Moscow, U.S.S.R.

G. F. Gause, Institute of New Antibiotics, Moscow, U.S.S.R.

American Type Culture Collection, Rockville, Md.

J. B. Routien, Pfizer Inc., Groton, Conn.

Laboratory of the authors

American Type Culture Collection, Rockville, Md.

R. J. Hosley, Eli Lilly and Co., Indianapolis, Ind.

American Type Culture Collection, Rockville, Md.

J. B. Routien, Pfizer Inc., Groton, Conn.

J. A. Bush, Bristol Laboratories, Syracuse, N.Y.

J. A. Bush, Bristol Laboratories, Syracuse, N.Y.

A. Seino, Kaken Chemical Co., Tokyo, Japan

F. Parenti, Gruppo Lepetit, Milan, Italy

W. E. Grundy, Abbott Laboratories, Chicago, Ill.

${ }^{a}$ Deposited by J. D. Skarbek with the American Type Culture Collection (ATCC 27627) and with the Northern Regional Research Center (NRRL B-8031).

${ }^{b}$ Deposited by J. D. Skarbek with the Northern Regional Research Center (NRRL B-8036).

${ }^{c}$ Deposited by J. D. Skarbek with the Northern Regional Research Center (NRRL B-8032).

${ }^{d}$ Deposited by J. D. Skarbek with the Northern Regional Research Center (NRRL B-8033).

e Sobin et al., U.S. Patents 3,646,194 and 3,906,093.

${ }^{f}$ Also available as ATCC 12956.

${ }^{g}$ Also deposited by J. D. Skarbek with the Northern Regional Research Center (NRRL B-8030). Refer to the accompanying paper (24) for the taxonomic description of $S$. cavourensis subsp. washingtonensis strain AUW-83.

${ }^{h}$ A. Miyake, K. Mizuno, K. Nakazawa, Y. Aramaki, and K. Kaziwara, U.S. Patent 3,313,691, 11 April 1967.

${ }^{i}$ No taxonomic information was to be found in the literature; identification of strain M5-18903 as $S$. lavendulae was through personal communication with R. J. Hosley.

'Also available as ATCC 12957.

${ }^{k}$ Produces the A-649 (olivomycin) complex of antibiotics.

' A chromomycin-producing strain isolated by in-house screening and not previously reported in the literature (J. A. Bush, personal communication).

${ }^{m}$ A reputed chromomycin-producing strain for which taxonomic information was not to be found in the literature. Strain KCC S-1081 was isolated by the Microbial Chemistry Research Laboratory (MCRL) of Tanabe Seiyaku Co., Saitama, Japan, from a soil sample collected in Nara Prefecture and deposited with A. Seino under the strain designation MCRL 0317 (personal communication from T. Okuda [MCRL] and from A. Seino).

${ }^{n}$ No taxonomic information was to be found in the literature. Two other aureolic acid-producing strains, NA 4-M40 and NA 4-X8, have been discarded and are no longer available (W. E. Grundy, personal communication). 
DB spectrophotometer, with or without prior dilution, from 500 to $300 \mathrm{~nm}$. Characteristic absorptions in this wavelength region (6) were taken as presumptive evidence for the presence of representative polyene metabolites extracted into the ethanol from the spores and aerial mycelia of the study strains.

For the determination of sodium chloride tolerance, the method of Tresner et al. (27) was followed. Yeastmalt extract agar was hydrated in sodium chloride solutions of $4,7,10$, and $13 \%$, dispensed into screw- capped culture tubes, and autoclaved. One set of tubed media covering the entire range of sodium chloride concentrations and one tube of medium without sodium chloride supplementation were used for each culture. The slanted culture media were inoculated with spores suspended in sterilized water, incubated at $28^{\circ} \mathrm{C}$ for 10 days, and then observed for the maximal sodium chloride concentration allowing any growth.

To confirm that these strains produced antibiotics belonging to the aureolic acid group, a limited trial



FIG. 1. Light micrographs of sporulating aerial mycelium of available strains of Actinomycetales reported to produce antibiotics of the chromomycin or olivomycin type. Magnification: $(1-4,6,8,11,12) \times 217:(5,7,9$, 10) $\times 347$. (1) Streptomyces aburaviensis ATCC 23869. RF morphology on inorganic salts-starch agar, 14 days. (2) S. griseus no. 7. RF morphology on yeast-malt extract agar, 14 days. (3) S. lavendulae M5.18903. S. morphology on oatmeal agar, 14 days. (4) $S$. minutiscleroticus ATCC 17757. $S$ morphology on yeast-malt extract agar, 14 days. Note sclerotia. (5) Actinomyces nigrificans INA 3014. S morphology on yeast-malt extract agar, 14 days. (6) $S$. cavourensis subsp. washingtonensis AUW-83. RF morphology on glycerolasparagine agar, 14 days. (7) Strain AUW-83 (single-spore isolate). RF morphology with occasional hook or loop (center of picture) on yeast-malt extract agar, 14 days. (8) Strain AUW-83 (single-spore isolate). RF morphology with incomplete spiral (lower left-hand corner of picture) on yeast-malt extract agar, 14 days. (9) Strain AUW-83 (single-spore isolate). RF morphology with incomplete spiral (slightly above center of picture) on yeast-malt extract agar, 14 days. (10) Streptomyces sp. C.1228. RF morphology on oatmeal agar, 14 days. (11) Streptomyces sp. C-14795. RF morphology on inorganic salts-starch agar, 14 days. (12) Streptomyces sp. KCC S-1081. RF morphology on yeast-malt extract agar, 14 days. 
was made using culture and bioassay conditions, extraction procedures, and thin-layer chromatographic methods reported previously (23). Finally, medium 42 (tyrosine-yeast extract agar) of Waksman (31) was employed to complement the standard ISP media used for detection of melanoid pigments.

\section{RESULTS}

Spore chain morphology. Light micrographs illustrating the sporophore morphologies of available cultures of Actinomycetales claimed to produce antibiotics of the chromomycin or olivomycin type and of the chromomycin-producing $S$. cavourensis subsp. washingtonensis strain AUW-83 are presented in Fig. 1. Light micrographs of some sporulating cultures of Actinomycetales claimed to produce antibiotics of the aureolic acid type are presented in Fig. 2. The study strains were observed to belong to the sections Rectiflexibiles or Spirales.

Spore characteristics. Electron micro- graphs illustrating the spore types of available cultures of Actinomycetales claimed to produce antibiotics of the chromomycin or olivomycin type and of the chromomycin-producing $S$. cavourensis subsp. washingtonensis strain AUW83 are presented in Fig. 3. Electron micrographs illustrating the spore types of some Actinomycetales claimed to produce antibiotics of the aureolic acid type are given in Fig. 4. The spore surfaces were found to be primarily of two types: smooth or spiny.

Color determinations. The mass colors of mature, sporulating aerial surface growth of all strains on standard media are presented in Table 2. The strains belonged to the Gray, White, Yellow, or Red color series of Tresner and Backus.

Distinctive pigments other than yellow-brown were observed in the reverse mycelium of only one strain, S. lavendulae M5-18903. The yellowbrown of the substrate mycelium was modified by a red pigment when the strain was grown on

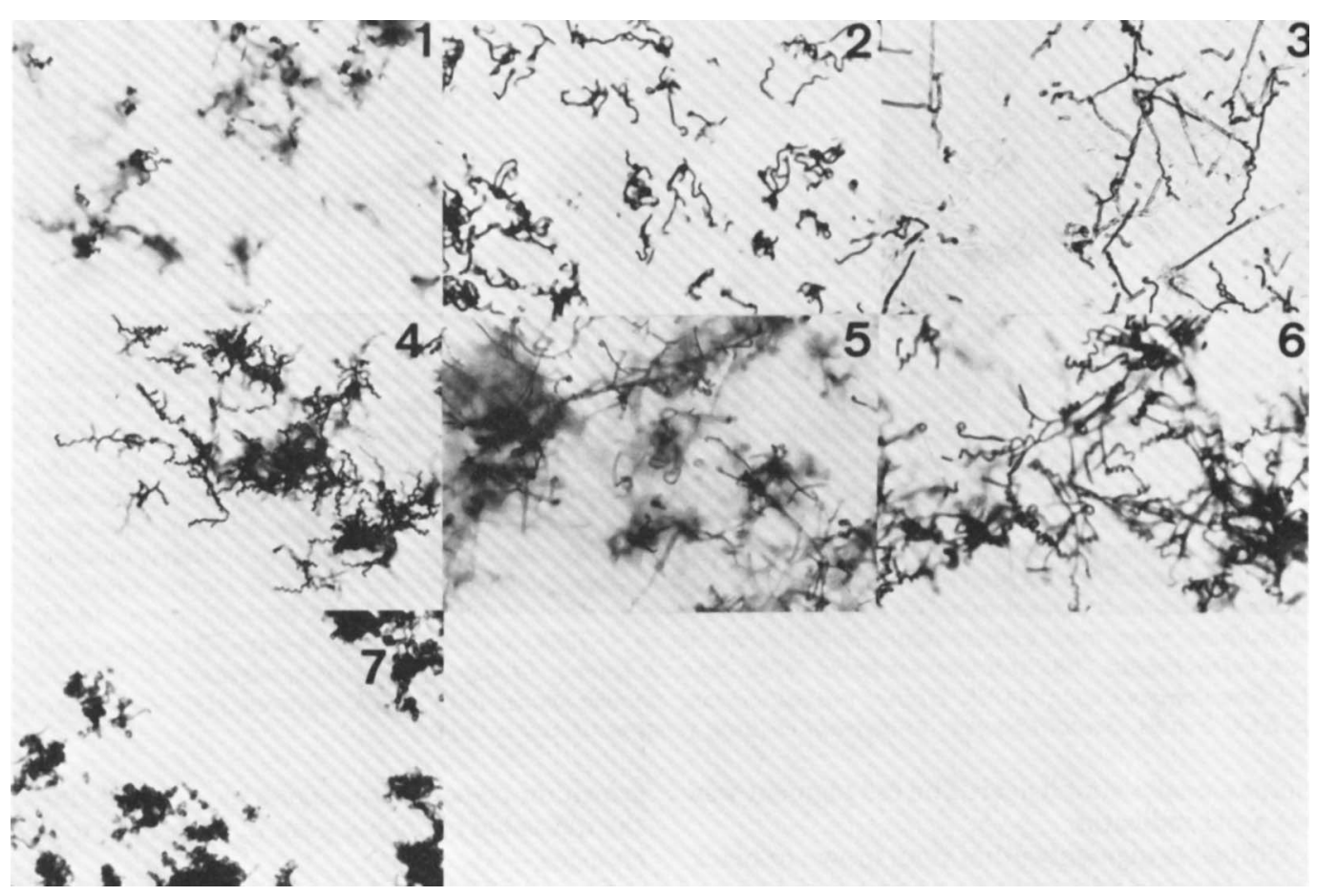

FIG. 2. Light micrographs of sporulating aerial mycelium of available strains of Actinomycetales reported to produce antibiotics of the aureolic acid type. Magnification: $(1,4) \times 226 ;(2,3,5-7) \times 360$. (1) Streptomyces argillaceus $F$. D.6590. S morphology on inorganic salts-starch agar, 14 days. (2) Actinomyces atroolivaceus INA 11294. S morphology on oatmeal agar, 14 days. (3) A. globisporus subsp. flavofuscus INA 11296. RF morphology, but crooked sporophores might suggest some $S$, on yeast-malt extract agar, 14 days. (4) $S$. plicatus F. D.13756. S morphology on yeast-malt extract agar, 14 days. (5) Streptomyces sp. L. A. 7017. S (tight terminal coils) morphology on oatmeal agar, 14 days. (6) Streptomyces sp. M-198. S morphology on inorganic salts-starch agar, 14 days. (7) A. variabilis INA 232. S (tight terminal coils) morphology on oatmeal agar, 14 days. 


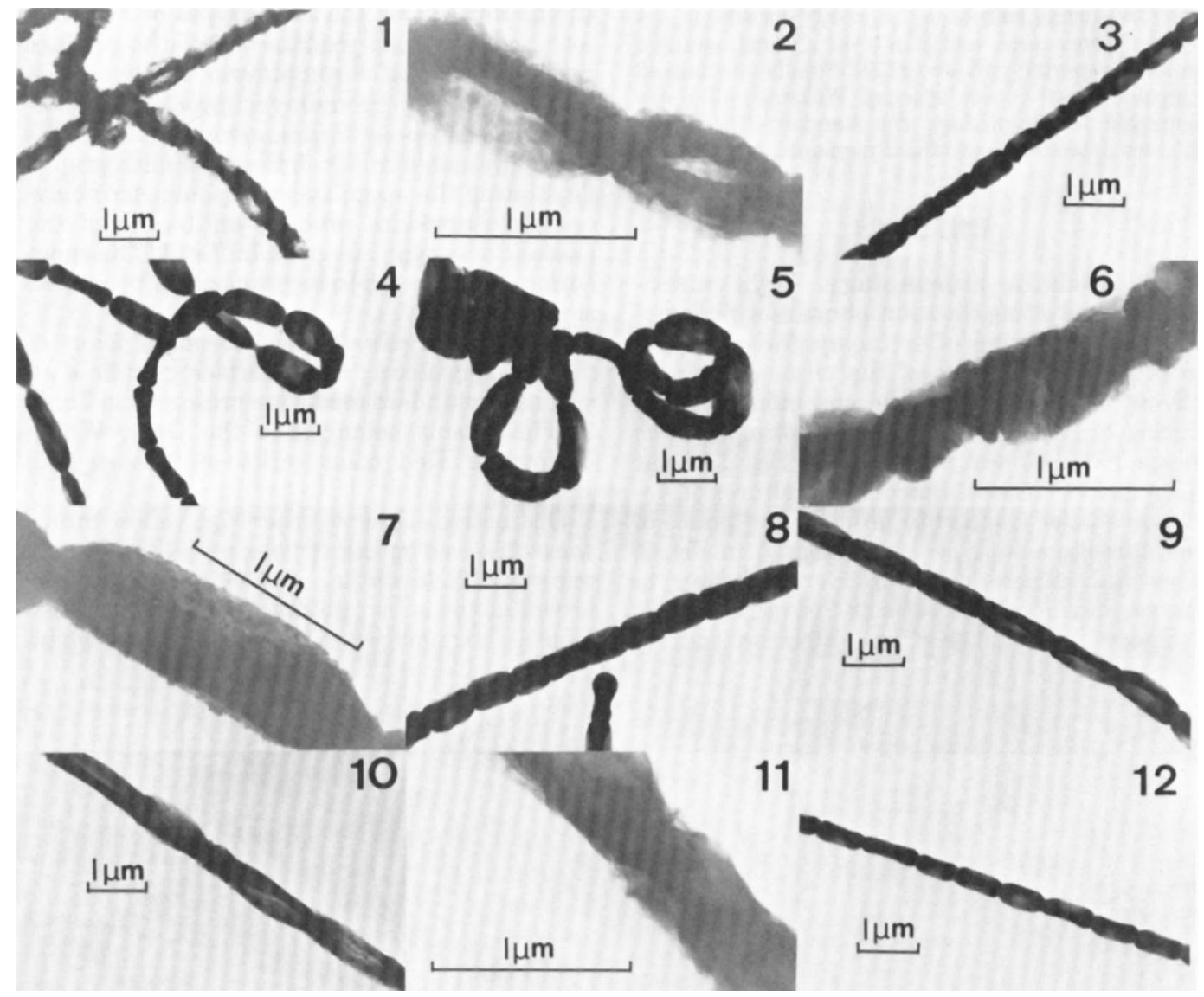

FIG. 3. Electron micrographs illustrating spore types of available strains of Actinomycetales reported to produce antibiotics of the chromomycin or olivomycin type. (1) Streptomyces aburaviensis ATCC 23869. Smooth spores; 14-day-old culture, inorganic salts-starch agar. (2) S. aburaviensis ATCC 23869. Higher magnification; smooth spores with rough surfaces. (3) S. griseus no. 7. Smooth spores; 14-day-old culture, yeast-malt extract agar. (4) S. lavendulae M5-18903. Smooth spores; 14-day-old culture, inorganic saltsstarch agar. (5) S. minutiscleroticus ATCC 17757. Smooth spores; 14-day-old culture, glycerol-asparagine agar. (6) Actinomyces nigrificans INA 3014. Smooth spores with rough surfaces; 14-day-old culture, inorganic salts-starch agar. (7) A. nigrificans INA 3014. Rough spore surfaces appearing to be warty; 14-day-old culture, yeast-malt extract agar. (8) S. cavourensis subsp. washingtonensis AUW-83. Smooth spores; 14-dayold culture, yeast-malt extract agar. (9) Streptomyces sp. C-1228. Smooth spores; 14-day-old culture, yeastmalt extract agar. (10) Streptomyces sp. C-14795. Smooth spores; 14-day-old culture, yeast-malt extract agar. (11) Streptomyces sp. C-14795. Higher magnification; smooth spores with rough surfaces. (12) Streptomyces sp. KCC S-1081. Smooth spores; 14-day-old culture, yeast-malt extract agar.

inorganic salts-starch agar. The red pigment was not a $\mathrm{pH}$ indicator.

Diffusible pigments other than brown or black were observed with only four strains. S. griseus no. 7 and Streptomyces sp. KCC S-1081 exhibited a yellow-brown coloration modified by a green pigment on inorganic salts-starch agar. S. lavendulae M5-18903 was observed to secrete a red pigment into inorganic salts-starch agar, and Streptomyces sp. L.A. 7017 was found to have a grayish-green diffusible pigment when grown on glycerol-asparagine agar. In all cases, the diffusible pigments were not sensitive to $\mathrm{pH}$ changes.

Observations on the production of melanoid pigments on standard media and on Waksman medium 42 are presented in Table 3. Approximately $40 \%$ of these strains were found to be capable of forming melanoid pigments.

Carbon utilization. The utilization of standard carbon sources for growth by all of the strains is given in Table 4. The utilization pat- 


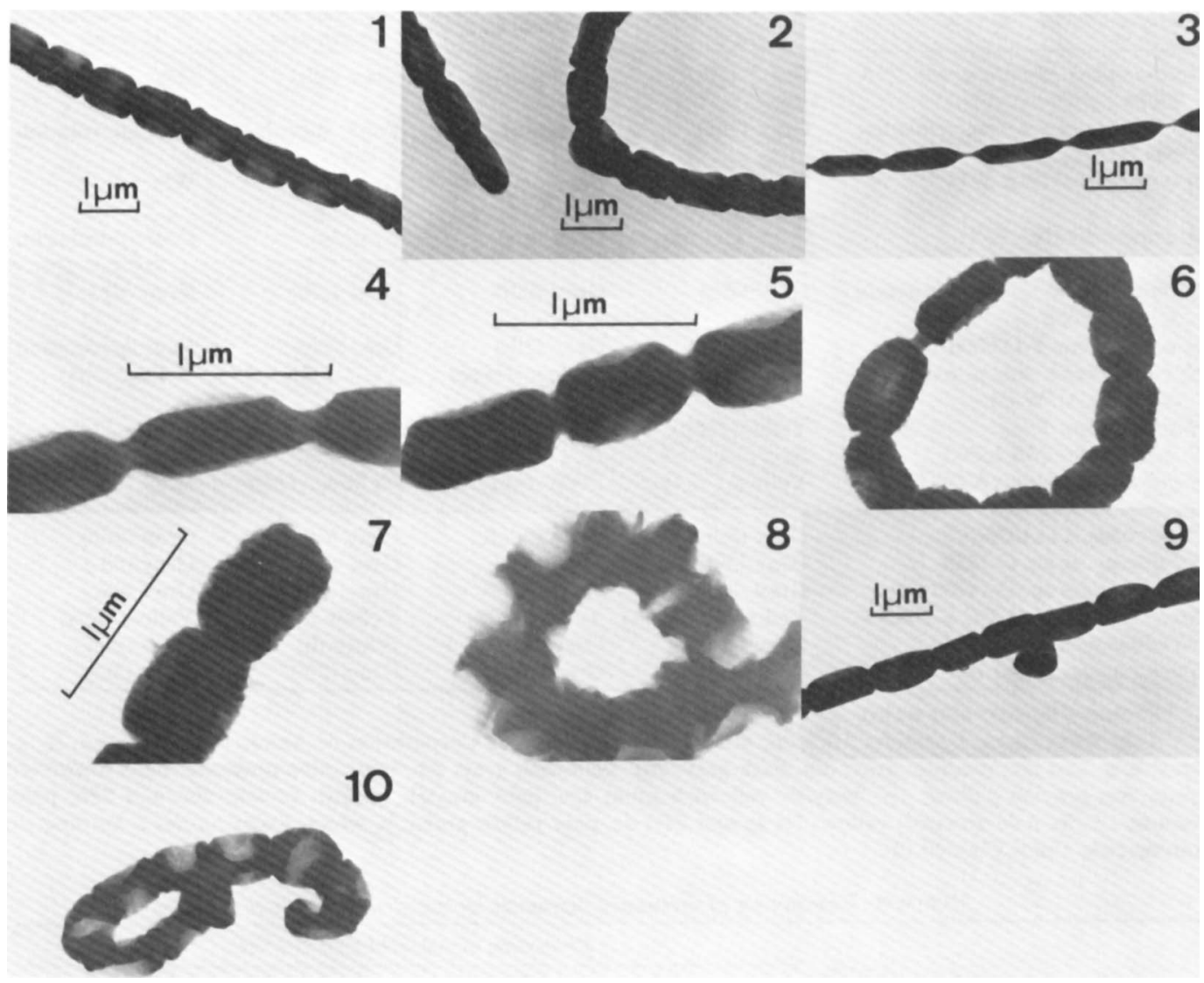

FIG. 4. Electron micrographs illustrating spore types of available strains of Actinomycetales reported to produce antibiotics of the aureolic acid type. (1) Streptomyces argillaceus F. D.6590. Smooth spores; 14-dayold culture, inorganic salts-starch agar. (2) Actinomyces atroolivaceus INA 11294. Smooth spores; 14-dayold culture, yeast-malt extract agar. (3) A. globisporus subsp. flavofuscus INA 11296. Smooth spores; 14-dayold culture, yeast-malt extract agar. (4) S. plicatus F. D.13756. Smooth spores; 14-day-old culture, glycerolasparagine agar. (5) S. plicatus F. D.13756. Smooth spores with only minor surface irregularities; 14-day-old culture, glycerol-asparagine agar. (6) S. plicatus F. D.13756. Spiny spores with short spines; 14-day-old culture, yeast-malt extract agar. (7) S. plicatus F. D.13756. Spiny spores with short spines; 14-day-old culture, glycerol-asparagine agar. (8) Streptomyces sp. L. A. 7017. Smooth spores; 14-day-old culture, oatmeal agar. (9) Streptomyces sp. M-198. Smooth spores; 14-day-old culture, yeast-malt extract agar. (10) A. variabilis INA 232. Smooth spores; 14-day-old culture, inorganic salts-starch agar.

terns were found to range from poor growth on nearly all carbon sources except glucose to good growth on all carbon sources.

Spectrophotometric analysis for polyenes. Of the strains studied, only the ethanolic extracts of sporulating cultures of Streptomyces sp. C-1228 exhibited absorption spectra characteristic of a polyene. The wavelength maxima observed at $340,360,380$, and $402 \mathrm{~nm}$ are characteristic of a heptaene (6).

Tolerance to sodium chloride. Results of the sodium chloride tolerance test are presented in Table 5. Two strains, S. aburaviensis ATCC
23869 and Streptomyces sp. C-14795, were unable to tolerate $4 \%$ sodium chloride. None of the study strains were observed to tolerate $13 \%$ sodium chloride.

Bioassay of fermentation broths and thin-layer chromatographic determination of production of aureolic acid group antibiotics. Results of the bioassays and of the thinlayer chromatographic analyses of the fermentation liquors of all strains are presented in Table 6. It was observed that the liquors of several strains previously reported to produce aureolic acid group antibiotics were devoid of 
TABLE 2. Spore mass color of the strains studied

\begin{tabular}{|c|c|c|c|c|}
\hline \multirow[b]{2}{*}{ Strain } & \multicolumn{4}{|c|}{ Spore mass color on: } \\
\hline & $\begin{array}{c}\text { Yeast-malt extract } \\
\text { agar }\end{array}$ & Oatmeal agar & $\begin{array}{l}\text { Inorganic salts- } \\
\text { starch agar }\end{array}$ & $\begin{array}{l}\text { Glycerol-aspara- } \\
\text { gine agar }\end{array}$ \\
\hline $\begin{array}{l}\text { Actinomyces atroolivaceus INA } \\
11294\end{array}$ & Gray $^{a}(3 \mathrm{ih})^{b}$ & Gray (3ih) & Gray (3ih) & Gray (e) \\
\hline $\begin{array}{l}\text { A. globisporus subsp. flavofus- } \\
\text { cus INA } 11296\end{array}$ & Gray (2dc) & White (b) & $\begin{array}{l}\text { Poor sporula- } \\
\text { tion }\end{array}$ & Poor sporulation \\
\hline A. nigrificans INA 3014 & Gray (d) & $\begin{array}{l}\text { Poor sporula- } \\
\text { tion }\end{array}$ & Gray (d) & White (b) \\
\hline A. variabilis INA 232 & $\begin{array}{l}\text { Poor sporula- } \\
\text { tion }\end{array}$ & Gray (g) & Gray (e) & Poor sporulation \\
\hline $\begin{array}{ll}\text { Streptomyces } & \text { aburaviensis } \\
\text { ATCC } 23869 & \end{array}$ & Gray (2ih) & Gray (2ih) & Gray (2ih) & Gray (d) \\
\hline S. argillaceus F.D.6590 & Gray (2ih) & Gray (2ih) & Gray (3fe) & Poor sporulation \\
\hline $\begin{array}{l}\text { S. cavourensis subsp. washing- } \\
\text { tonensis AUW-83 }\end{array}$ & Yellow $(11 / 2$ ec) & Yellow (11/2 ec) & Yellow (11/2 ec) & Yellow (2ba) \\
\hline S. griseus no. 7 & Yellow (2db) & Yellow $\left(1 \frac{1}{2} \mathrm{db}\right)$ & Yellow (11/2db) & Yellow (2db) \\
\hline S. lavendulae M5-18903 & Red (3ec) & $\operatorname{Red}(4 \mathrm{ec})$ & Red (4ge) & Red (3ec) \\
\hline S. minutiscleroticus ATCC 17757 & $\begin{array}{l}\text { Yellow } \quad(241 / 2 \\
\text { dc) }\end{array}$ & $\begin{array}{l}\text { Poor sporula- } \\
\text { tion }\end{array}$ & $\begin{array}{l}\text { Yellow }(241 / 2 \\
\text { dc) }\end{array}$ & Gray (2fe) \\
\hline S. plicatus F.D.13756 & Gray (3ih) & Gray (2dc) & Gray (d) & Gray (2dc) \\
\hline Streptomyces sp. C-1228 & Gray (3ih) & Gray (3ih) & Gray (3ih) & Gray (3ih) \\
\hline Streptomyces sp. C-14795 & Gray (3fe) & Gray (e) & Gray (2ih) & Gray (2dc) \\
\hline Streptomyces sp. KCC S-1081 & Yellow (2db) & Yellow (2db) & Yellow (2db) & Yellow (2ba) \\
\hline Streptomyces sp. L.A. 7017 & Gray (2dc) & Gray (2dc) & White (b) & Gray (2fe) \\
\hline Streptomyces sp. M-198 & Gray (3ih) & Gray (3ih) & Gray (3fe) & Gray (3fe) \\
\hline
\end{tabular}

a Tresner-Backus color series.

b Tabs from Color Harmony Manual, 4th ed., 1958 (Container Corporation of America, Chicago): d, light gray; e, g, and 2fe, medium gray; 3ih, dark gray; 2dc, yellowish gray; 2ih, light olive gray; 3fe, light brownish gray; 3ec, grayish yellow; 4ec, grayish yellowish pink; 4ge, light grayish reddish brown; 2ba and 2db, pale yellow; $1 \frac{1}{2} \mathrm{db}$, pale greenish yellow; $1 \frac{1}{2} \mathrm{ec}$ and $24 \frac{1}{2} \mathrm{dc}$, pale yellow green; $b$, white. Color names according to Intersociety Color Council (9).

TABLE 3. Production of melanoid pigments by the strains studied

\begin{tabular}{|c|c|c|c|c|}
\hline \multirow{3}{*}{ Strain } & \multicolumn{4}{|c|}{ Production of melanoid pigments ${ }^{a}$ on: } \\
\hline & \multicolumn{3}{|c|}{ ISP medium } & \multirow{2}{*}{ Waksman medium 42} \\
\hline & No. 1 & No. 6 & No. 7 & \\
\hline $\begin{array}{r}\text { Actinomyces atroolivaceus } \\
\text { INA } 11294\end{array}$ & - & - & - & - \\
\hline $\begin{array}{l}\text { A. globisporus subsp. flavo- } \\
\text { fuscus INA } 11296\end{array}$ & $\mathbf{S}$ & $\mathrm{S}$ & - & - \\
\hline A. nigrificans INA 3014 & + & + & + & + \\
\hline A. variabilis INA 232 & - & - & $\mathbf{S}$ & - \\
\hline $\begin{array}{l}\text { Streptomyces aburaviensis } \\
\text { ATCC } 23869\end{array}$ & - & - & - & - \\
\hline S. argillaceus F.D.6590 & + & + & + & + \\
\hline $\begin{array}{l}\text { S. cavourensis subsp. wash- } \\
\text { ingtonensis AUW-83 }\end{array}$ & + & + & $++^{b}$ & + \\
\hline S. griseus no. 7 & - & - & $\mathbf{S}$ & - \\
\hline S. lavendulae M5-18903 & + & + & + & + \\
\hline $\begin{array}{l}\text { S. minutiscleroticus ATCC } \\
17757\end{array}$ & $\mathbf{S}$ & - & $-c$ & $-d$ \\
\hline S. plicatus F.D.13756 & $\mathbf{S}$ & $\mathbf{S}$ & $\mathbf{S}$ & - \\
\hline Streptomyces sp. C-1228 & $\mathbf{S}$ & - & $\mathbf{S}$ & $-c$ \\
\hline Streptomyces sp. C-14795 & $\mathbf{S}$ & - & $\mathbf{S}$ & - \\
\hline Streptomyces sp. KCC S-1081 & - & - & $\mathbf{S}$ & - \\
\hline Streptomyces sp. L.A. 7017 & + & + & + & + \\
\hline Streptomyces sp. M-198 & + & + & + & + \\
\hline
\end{tabular}

${ }^{a}$ Symbols: + , positive; - , negative; $S$, only trace browning was observed, probably indicative of a negative melanin test, with some strains.

${ }^{b}$ Definite browning was observed beneath sporulating aerial mycelium, which had developed at the top of the test slants; only trace browning occurred where growth was present but no aerial mycelium had appeared.

c A blue-green diffusible pigment was observed.

${ }^{d}$ A red-yellow diffusible pigment was observed. 
TABLE 4. Utilization of carbon sources for growth by the strains studied ${ }^{a}$

\begin{tabular}{|c|c|c|c|c|c|c|c|c|}
\hline \multirow{2}{*}{ Strain } & \multicolumn{8}{|c|}{ Result of test for the utilization of: } \\
\hline & $\begin{array}{c}\text { L-Arabi- } \\
\text { nose }\end{array}$ & D-Xylose & $\begin{array}{l}\text { D-Fruc- } \\
\text { tose }\end{array}$ & $\begin{array}{c}\begin{array}{c}\text { D-Manni- } \\
\text { tol }\end{array} \\
\end{array}$ & $\begin{array}{l}\text { meso-Ino- } \\
\text { sitol }\end{array}$ & $\begin{array}{c}\text { D-Raffi- } \\
\text { nose }\end{array}$ & $\begin{array}{c}\text { L-Rham- } \\
\text { nose }\end{array}$ & D-Sucrose \\
\hline $\begin{array}{r}\text { Actinomyces atrooli- } \\
\text { vaceus INA } 11294\end{array}$ & + & + & ++ & ++ & - & + & - & + \\
\hline $\begin{array}{l}\text { A. globisporus subsp. } \\
\text { flavofuscus INA } \\
11296\end{array}$ & - & - & ++ & - & ++ & - & - & ++ \\
\hline A. nigrificans INA & ++ & ++ & ++ & ++ & ++ & ++ & ++ & ++ \\
\hline A. variabilis INA 232 & - & + & ++ & + & + & + & - & ++ \\
\hline $\begin{array}{ll}\text { Streptomyces } & \text { abura } \\
\text { viensis } & \text { ATCC } \\
23869 & \end{array}$ & \pm & - & - & - & - & \pm & - & - \\
\hline $\begin{array}{l}\text { S. argillaceus F.D.- } \\
6590\end{array}$ & ++ & ++ & ++ & ++ & ++ & - & ++ & - \\
\hline $\begin{array}{l}\text { S. cavourensis subsp. } \\
\text { washingtonensis } \\
\text { AUW-83 }\end{array}$ & ++ & ++ & ++ & ++ & - & - & - & - \\
\hline S. griseus no. 7 & \pm & ++ & ++ & ++ & - & - & ++ & - \\
\hline $\begin{array}{l}\text { S. lavendulae M5- } \\
18903\end{array}$ & - & + & + & - & - & - & - & - \\
\hline $\begin{array}{l}\text { S. minutiscleroticus } \\
\text { ATCC } 17757\end{array}$ & + & + & + & ++ & \pm & - & ++ & - \\
\hline S. plicatus F.D.13756 & + & + & + & ++ & ++ & - & ++ & - \\
\hline $\begin{array}{l}\text { Streptomyces sp. C- } \\
1228\end{array}$ & ++ & ++ & ++ & - & - & - & - & + \\
\hline $\begin{array}{l}\text { Streptomyces sp. C- } \\
\quad 14795\end{array}$ & + & \pm & - & - & - & - & - & \pm \\
\hline $\begin{array}{l}\text { Streptomyces } \\
\text { KCC S-1081 }\end{array}$ & ++ & + & + & ++ & - & - & ++ & - \\
\hline $\begin{array}{l}\text { Streptomyces } \\
\text { L.A. } 7017\end{array}$ & ++ & ++ & ++ & ++ & ++ & + & ++ & - \\
\hline $\begin{array}{l}\text { Streptomyces sp. M- } \\
\quad 198\end{array}$ & ++ & ++ & ++ & ++ & ++ & - & ++ & - \\
\hline
\end{tabular}

a Symbols: -, negative response; \pm , doubtful response; + , more growth than with carbon control but less than with glucose; ++ , positive response equal to the amount of growth with glucose.

activity under the test conditions; among these were Actinomyces nigrificans INA 3014, S. aburaviensis ATCC 23869, S. lavendulae M5-18903, S. minutiscleroticus ATCC 17757, Streptomyces sp. C-1228, and Streptomyces sp. KCC S-1081. Except for the single olivomycin-producing strain in the study, Streptomyces sp. C-1228, all of the last-mentioned strains have been claimed to produce antibiotics of the chromomycin type. Other culture conditions or similarly important variables may be conducive for the production of detectable amounts of these antibiotics. However, it has been previously observed (23) that continuous subculturing of the chromomycinproducing strain AUW-83 resulted in a remarkably reduced capability of this strain to produce significant amounts of the chromomycins. Comparison of thin-layer chromatograms of ethyl acetate extracts of the fermentation broths of the remaining strains with authentic reference samples of mithramycin, chromomycin $A_{3}$, and olivomycin A indicated that these strains were consistent with the available information concerning their production of these antibiotics.

\section{DISCUSSION}

A summary of the types of aureolic acid group antibiotics produced, the primary characters, and the carbon utilization patterns of the strains studied is presented in Table 7. Two of these strains, S. aburaviensis ATCC 23869 and $S$. minutiscleroticus ATCC 17757, are type strains and were previously evaluated in the ISP (21, 22). Similarities in taxonomic characters suggest that both Bristol's strain C-14795 and $S$. aburaviensis ATCC 23869, which produce chromomycins, are different strains of the same species. Sporophore morphology, spore surface, color of sporulating aerial mycelium, and a negative melanin test, features regarded by Gottlieb and Shirling (5) as primary taxonomic characters, are the same for both strains. The carbon utili- 
TABLE 5. Sodium chloride tolerances of the strains studied

\begin{tabular}{lc}
\hline \multicolumn{1}{c}{ Strain } & $\begin{array}{c}\text { Sodium chloride tol- } \\
\text { erance }\end{array}$ \\
\hline $\begin{array}{l}\text { Actinomyces atroolivaceus } \\
\text { INA 11294 }\end{array}$ & $\geq 7 \%$ but $<10 \%$ \\
$\begin{array}{l}\text { A. globisporus subsp. flavofus- } \\
\text { cus INA 11296 }\end{array}$ & $\geq 7 \%$ but $<10 \%$ \\
A. nigrificans INA 3014 & $\geq 7 \%$ but $<10 \%$ \\
$\begin{array}{l}\text { A. variabilis INA 232 } \\
\text { Streptomyces aburaviensis }\end{array}$ & $\geq 4 \%$ but $<7 \%$ \\
ATCC 23869 & $<4 \%$ \\
S. argillaceus F.D.6590 & $\geq 7 \%$ but $<10 \%$ \\
S. cavourensis subsp. washing- & $\geq 7 \%$ but $<10 \%$ \\
$\quad$ tonensis AUW-83 & $\geq 7 \%$ but $<10 \%$ \\
S. griseus no. 7 & $\geq 7 \%$ but $<10 \%$ \\
S. lavendulae M5-18903 & $\geq 7 \%$ but $<10 \%$ \\
S. minutiscleroticus ATCC & \\
17757 & $\geq 10 \%$ but $<13 \%$ \\
S. plicatus F.D.13756 & $\geq 4 \%$ but $<7 \%$ \\
Streptomyces sp. C-1228 & $<4 \%$ \\
Streptomyces sp. C-14795 & $\geq 10 \%$ but $<13 \%$ \\
Streptomyces sp. KCC S-1081 & $\geq 7 \%$ but $<10 \%$ \\
Streptomyces sp. L.A. 7017 & $\geq 7 \%$ but $<10 \%$ \\
Streptomyces sp. M-198 &
\end{tabular}

zation patterns are distinctively similar in that cultures of both strains grew poorly on almost all of the carbon sources except glucose. Of the additional taxonomic characters evaluated, the inability of both strains to tolerate $4 \%$ sodium chloride is noteworthy. These were the only two strains in the study which were unable to tolerate this low concentration of sodium chloride. The results of a study by Tresner et al. (27), who proposed the use of tolerance of sodium chloride for the taxonomy of streptomycetes, indicated that about $5 \%$ of the 313 species studied could not tolerate $4 \%$ sodium chloride.

Another pair of chromomycin-producing strains which may be considered different strains of the same species are $S$. griseus no. 7 and Streptomyces sp. KCC S-1081. The primary characters of these two strains are the same, and the carbon utilization patterns differ only with respect to arabinose, but members of the "griseus" group are known to be variable in the utilization of this carbon source (14). The production by these strains of a soluble green pigment in inorganic salts-starch agar is a distinctive characteristic. Streptomyces $\mathrm{sp}$. KCC S-1081 tolerated $10 \%$ sodium chloride better than did strain no. 7 , but the study by Tresner et al. (27) indicated that nearly as many species of the yellow color series could tolerate $10 \%$ sodium chloride as could tolerate $7 \%$, and therefore this difference may not be important. A deoxyribonucleic acid-deoxyribonucleic acid homology test would be useful in assessing the subspecific relationship of these two strains.
TABLE 6. Results of the bioassays and of the thinlayer chromatographic analyses of broths fermented by the strains studied

\begin{tabular}{|c|c|c|}
\hline Strain & $\begin{array}{c}\text { Bioassay }^{a} \\
\text { of fermen- } \\
\text { tation } \\
\text { broth } \\
(\mu \mathrm{g} / \mathrm{ml}) \\
\end{array}$ & $\begin{array}{l}\text { Type }{ }^{b} \text { of aureolic } \\
\text { acid group anti- } \\
\text { biotic produced }\end{array}$ \\
\hline $\begin{array}{l}\text { Actinomyces atrooliva- } \\
\text { ceus INA } 11294\end{array}$ & 5 & Aureolic acid \\
\hline $\begin{array}{l}\text { A. globisporus subsp. } \\
\text { flavofuscus } \\
11296\end{array}$ & 69 & Aureolic acid \\
\hline $\begin{array}{l}\text { A. nigrificans INA } 3014 \\
\text { A. variabilis INA } 232\end{array}$ & $\begin{array}{l}\mathrm{ND}^{\mathrm{c}} \\
69\end{array}$ & $\begin{array}{c}\mathrm{N}^{c} \\
\text { Aureolic acid }\end{array}$ \\
\hline $\begin{array}{c}\text { Streptomyces abura } \\
\text { viensis ATCC } 23869\end{array}$ & ND & $\mathbf{N}$ \\
\hline S. argillaceus F.D.6590 & 49 & Aureol \\
\hline $\begin{array}{l}\text { S. cavourensis subsp. } \\
\text { washingtonensis } \\
\text { AUW-83 }\end{array}$ & 260 & $\operatorname{cin}$ \\
\hline $\begin{array}{l}\text { S. griseus no. } 7 \\
\text { S. lavendulae M5-18903 }\end{array}$ & $\begin{array}{c}35 \\
\text { ND }\end{array}$ & $\begin{array}{l}\text { Chromomycin } \\
\mathbf{N}\end{array}$ \\
\hline $\begin{array}{l}\text { S. minutiscleroticus } \\
\text { ATCC } 17757\end{array}$ & ND & $\mathrm{N}$ \\
\hline S. plicatus F.D.13756 & 34 & Aureolic acid \\
\hline Streptomyces sp. C-1228 & ND & \\
\hline $\begin{array}{l}\text { Streptomyces } \\
14795\end{array}$ sp. C- & 142 & Chromomycin \\
\hline $\begin{array}{l}\text { Streptomyces sp. KCC } \\
\text { S-1081 }\end{array}$ & ND & $\mathbf{N}$ \\
\hline $\begin{array}{l}\text { Streptomyces sp. L.A. } \\
7017\end{array}$ & 14 & Aureolic acid \\
\hline Streptomyces sp. M-198 & 7 & Aureolic acid \\
\hline
\end{tabular}

${ }^{a}$ A paper disk agar diffusion method with Staphy. lococcus aureus NRRL B-313 as the test organism was employed; chromomycin $\mathbf{A}_{3}$, lot no. AUW-83- $\mathbf{A}_{3}$ $A \# 1$ (23), was used as a reference standard to which the antibiotic activities of the study broths were compared.

${ }^{b}$ Ethyl acetate extracts of fermentation broths were concentrated in vacuo, and thin-layer chromatographic comparisons were made with authentic reference samples of mithramycin, chromomycin $A_{3}$, and olivomycin A.

' Symbols: N, no aureolic acid group antibiotics detected; ND, no detectable activity.

A third pair of strains believed to belong to the same species are Pfizer's $S$. argillaceus F.D.6590 and Abbott's Streptomyces sp. M-198, both producers of the antibiotic aureolic acid (= mithramycin). The four primary characters and the carbon utilization patterns of these strains are identical. S. argillaceus was proposed as a new species in the patent literature (B. A. Sobin, J. B. Routien, K. V. Rao, W. S. Marsh, and A. L. Garretson, U.S. Patent 3,646,194, 29 February 1972, and U.S. Patent 3,906,093, 16 September 1975); however, patent publications contravene Rule 25b of the Bacteriological Code, 1976 revision (10), and therefore the name 
TABLE 7. Summary of the types of aureolic acid group antibiotics produced, the primary characters, and the utilizations of carbon sources for growth of the strains studied

\begin{tabular}{|c|c|c|c|c|c|c|c|c|c|c|c|c|c|c|}
\hline \multirow{2}{*}{$\begin{array}{l}\text { Specific name of } \\
\text { strain as received }\end{array}$} & \multirow{2}{*}{$\begin{array}{c}\text { Strain desig- } \\
\text { nation }\end{array}$} & \multirow{2}{*}{$\begin{array}{c}\text { Type }{ }^{a} \text { of au- } \\
\text { reolic acid group } \\
\text { antibiotic pro- } \\
\text { duced }\end{array}$} & \multicolumn{4}{|c|}{ Primary characters $^{b}$} & \multicolumn{8}{|c|}{ Utilization $^{c}$ of: } \\
\hline & & & SM & SS & CM & MR & Ab & Xy & Fr & Mt & Is & Rf & $\mathbf{R h}$ & $\mathrm{Su}$ \\
\hline $\begin{array}{l}\text { Streptomyces gri- } \\
\text { seus }\end{array}$ & No. 7 & Chromomycin & $R F$ & Sm & $\mathbf{Y}$ & - & \pm & + & + & + & - & - & + & - \\
\hline Streptomyces sp. & KCC S-1081 & NC & $R F$ & Sm & $\mathbf{Y}$ & - & + & + & + & + & - & - & + & - \\
\hline $\begin{array}{l}\text { S. cavourensis } \\
\text { subsp. washing- } \\
\text { tonensis }\end{array}$ & At & Chromomycin & $R F$ & Sm & $\mathbf{Y}$ & + & + & + & + & + & - & - & - & - \\
\hline S. aburaviensis & ATCC 23869 & Chromomycin & $R F$ & $\mathrm{Sm}$ & Gy & - & \pm & - & - & - & - & \pm & - & - \\
\hline Streptomyces sp. & C-14 & Chromomycin & $R F$ & $\mathrm{Sm}$ & Gy & - & + & \pm & - & - & - & - & - & \pm \\
\hline Streptomyces sp. & C-12 & Olivomycin & $R F$ & $\mathrm{Sm}$ & Gy & - & + & + & + & - & - & - & - & + \\
\hline $\begin{array}{l}\text { Actinomyces glob- } \\
\text { isporus subsp. } \\
\text { flavofuscus }\end{array}$ & INA 11296 & Aureolic acid & $R F^{d}$ & $\mathrm{Sm}$ & $\begin{array}{l}\text { Gy, } \\
\text { Wh }\end{array}$ & - & - & - & + & - & + & - & - & + \\
\hline A. variabilis & INA & Aureolic acid & $S$ & Sm & Gy & - & - & + & + & + & + & + & - & + \\
\hline A. atroolivaceus & INA & Aureolic acid & $S$ & Sm & Gy & - & + & + & + & + & - & + & - & + \\
\hline plicat & F.D.1 & Aureolic acid & $S$ & $\begin{array}{l}\text { Sp, } \\
\text { Sm }\end{array}$ & Gy & - & + & + & + & + & + & - & + & - \\
\hline $\begin{array}{l}\text { S. minutiscleroti- } \\
\text { cus }\end{array}$ & ATCC 17757 & NC & $S$ & $\mathrm{Sm}$ & Gy, & - & + & + & + & + & \pm & - & + & - \\
\hline S. argillaceus & F.D.6590 & Aureolic acid & $S$ & Sm & Gy & + & + & + & + & + & + & - & + & - \\
\hline Streptomyces sp. & M-198 & Aureolic acid & $S$ & $\mathrm{Sm}$ & Gy & + & + & + & + & + & + & - & + & - \\
\hline Streptomyces sp. & L.A. 7017 & Aureolic acid & $S$ & Sm & $\begin{array}{l}\text { Gy, } \\
\text { Wh }\end{array}$ & + & + & + & + & + & + & + & + & - \\
\hline A. nigrificans & INA 3014 & NC & $S$ & $\begin{array}{l}\text { Sm, } \\
\text { Wa }\end{array}$ & $\begin{array}{l}\text { Gy, } \\
\text { Wh }\end{array}$ & + & + & + & + & + & + & + & + & + \\
\hline S. lavendulae & M5-18903 & Chromomycin & $S$ & $\mathrm{Sm}$ & $\mathbf{R}$ & + & - & + & + & - & - & - & - & - \\
\hline
\end{tabular}

${ }^{a}$ See Skarbek and Brady (23) for a chronological listing, including antibiotic names and references to the chemical literature, of reported antibiotic substances belonging to the aureolic group. NC, Confirmation by thin-layer chromatographic analysis in a limited fermentation study was lacking, and the reported experimental data for the rantibiotic substances do not allow their absolute placement within a structural type (aureolic acid, chromomycin, or olivomycin type) of the aureolic acid group; the antibiotics produced by strains KCC S-1081, ATCC 17757, and INA 3014 possibly may have been of the chromomycin type.

${ }^{b}$ Abbreviations: SM, spore-chain morphology (S, Spirales; RF, Rectiflexibiles); SS, spore characteristics (Sm, smooth; Wa, warty; Sp, spiny); CM, aerial mass color (Gy, gray; R, red; Y, yellow; Wh, white); MR, melanoid pigmentation (-, negative; + , positive).

'Symbols: -, No utilization; \pm , doubtful utilization; +, positive utilization for growth. Abbreviations: Ab, arabinose; Xy, xylose; Fr, fructose; Mt, mannitol; Is, inositol; Rf, raffinose; Rh, rhamnose; and Su, sucrose.

${ }^{d}$ The presence of crooked sporophores, in addition to $R F$ morphology, observed in the microscopic examinations of strain INA 11296 might suggest placement in the category Spirales. All other strains in this study alleged to produce antibiotics of the aureolic acid type were observed to have $S$ morphologies.

S. argillaceus was not effectively published and hence has no standing in bacteriological nomenclature.

The remaining strains can be differentiated from the other strains in the study and from each other with regard to primary characters, carbon utilization patterns, and additional features, and therefore are probably members of different species.

S. cavourensis subsp. washingtonensis strain AUW-83 is a member of the griseus series, but it differs from strains no. 7 and KCC S-1081 regarding soluble pigment production in inorganic salts-starch agar, melanin production, and the utilization of rhamnose for growth. Strains no. 7 and KCC S-1081, but not strain AUW-83, were observed to form a soluble green pigment in inorganic salts-starch agar. Strain AUW-83 was capable of forming melanin pigments in several tyrosine-containing media; strains no. 7 and KCC S-1081 were not observed to form melanoid pigments in these media. Strains no. 7 and KCC S-1081 were able to utilize rhamnose for growth, but strain AUW-83 was not.

There have been several reports in the literature claiming the discovery of additional strains producing antibiotics belonging to the aureolic acid group; however, these strains were not available for this study, and the taxonomic information to be found in the literature on these strains was sometimes very sketchy. A list of additional strains reported to produce antibiotics of the aureolic acid group and available taxonomic information on these strains, together with pertinent references, is presented in Table 8. S. cavourensis subsp. washingtonensis strain AUW-83 appears to be quite distinct not only from the strains included in this study but also 
TABLE 8. Information regarding additional strains of Actinomycetales reported to produce antibiotics of the aureolic acid group

\begin{tabular}{|c|c|c|c|c|c|c|c|}
\hline \multirow{2}{*}{ Strain } & \multirow{2}{*}{$\begin{array}{c}\text { Antibiotic(s) }{ }^{a} \text { pro- } \\
\text { duced }\end{array}$} & \multicolumn{4}{|c|}{ Primary characters ${ }^{h}$} & \multirow{2}{*}{ Carbon utilization } & \multirow{2}{*}{$\begin{array}{l}\text { Source of } \\
\text { informa- } \\
\text { tion (lit- } \\
\text { erature } \\
\text { refer- } \\
\text { ences) }\end{array}$} \\
\hline & & SM & SS & CM & MR & & \\
\hline $\begin{array}{l}\text { Actinomyces abura- } \\
\text { viensis subsp. verru- } \\
\text { cosus } 144-3\end{array}$ & Chromomycins & & $\mathbf{W a}$ & & & & 29,30 \\
\hline $\begin{array}{l}\text { A. halstedii INA } 7193 \\
\text { A. iverini (strain } \\
\text { not mentioned) }\end{array}$ & $\begin{array}{l}7193 \\
\text { Mithramycin }^{c}\end{array}$ & $S$ & & Gy & - & & $-^{28}$ \\
\hline $\begin{array}{l}\text { A. olivovariabilis } 6604- \\
\text { - }\end{array}$ & Variamycin $^{e}$ & $S$ & $\mathrm{Sm}$ & Gy & - & $\begin{array}{l}\text { Glucose, arabinose, xy- } \\
\text { lose, and inositol are } \\
\text { utilized for growth; } \\
\text { no growth with man- } \\
\text { nitol, raffinose, and } \\
\text { rhamnose, and } \\
\text { growth on sucrose is } \\
\text { doubtful }\end{array}$ & $17,-f$ \\
\hline $\begin{array}{l}\text { Streptomyces fulvorec- } \\
\text { tus B-599 }\end{array}$ & Chromomycins & $R F$ & $\mathrm{Sm}$ & Gy & & & 11,12 \\
\hline $\begin{array}{l}\text { S. griseus } \text { SK-229 } \\
\text { S. katsunumaensis }\end{array}$ & $\begin{array}{l}\text { Chromomycins } \\
\text { Chromomycins }^{h}\end{array}$ & $R F$ & $\mathrm{Sm}$ & $\mathrm{Y}$ & - & & $\overline{15}^{g}$ \\
\hline $\begin{array}{l}\text { A468 = FERM-P } \\
2071\end{array}$ & $(=$ SR1768) & & & & & & \\
\hline $\begin{array}{l}\text { S. olivochromogenes } \\
69895\end{array}$ & Chromomycins & $S$ & $\mathrm{Sm}$ & Gy & + & $\begin{array}{l}\text { Glucose, arabinose, xy- } \\
\text { lose, fructose, man- } \\
\text { nitol, inositol, raffi- } \\
\text { nose, and rhamnose } \\
\text { are utilized for } \\
\text { growth; growth with } \\
\text { sucrose is doubtful }\end{array}$ & $7^{j}$ \\
\hline $\begin{array}{l}\text { S. olivoreticuli } \\
\text { INA } 16749\end{array}$ & Olivomycins & $V$ & & & & & 3,28 \\
\hline Streptomyces sp. 24-10 & $24-10$ & $S$ & & Gy & & $\begin{array}{l}\text { Glucose, arabinose, and } \\
\text { raffinose are utilized } \\
\text { for growth; utiliza- } \\
\text { tion of mannitol and } \\
\text { sucrose is doubtful }\end{array}$ & 2 \\
\hline Streptomycessp.C-2449 & C-2449 & & & & & & 8 \\
\hline
\end{tabular}

a The experimental data reported for some of these antibiotics do not allow for their absolute placement within a structural type (aureolic acid, chromomycin, or olivomycin type) of the aureolic acid group; the antibiotics produced by strains C-2449 and INA 7193 may possibly be of the aureolic acid type, and by strain 24-10, of the chromomycin type.

${ }^{b}$ Abbreviations: SM, spore-chain morphology (S, Spirales; RF, Rectiflexibiles; V, Verticillati); SS, spore characteristics (Sm, smooth; Wa, warty); CM, aerial mass color (Gy, gray; Y, yellow); MR, melanoid pigmentation $(-$, negative; + , positive).

'Mithramycin is structurally identical to aureolic acid.

${ }^{d}$ I. Gado, J. Gyimesi, E. Gal, I. Horvath, K. Magyar, B. Doczi, and M. Halasz, Hungarian Patent 155,679, February 1969.

- Variamycin is a structural analog of aureolic acid, differing by the substitution of the sugar, variose, for mycarose.

J. V. Zhdanovich, G. B. Lokshin, A. D. Kuzovkov, S. M. Rudaya, and N. K. Solovieva, U.S. Patent $3,821,085$, June 1974.

${ }^{g}$ Shionogi and Co., Japanese Patent 11,047, 1964. Taxonomic information on S. griseus SK-229 was received through personal communication with Y. K. Sawa, Shionogi and Co., Osaka, Japan.

${ }^{h} \mathrm{SR} 1768 \mathrm{~A}=$ cytrimycin, a structural analog of chromomycin $\mathrm{A}_{2} ; \mathrm{SR} 1768 \mathrm{~B}=$ chromomycin $\mathrm{A}_{2} ; \mathrm{SR} 1768 \mathrm{E}=$ chromomycin $\mathrm{A}_{3}$.

'T. Oki, Y. Matsuzawa, K. Numata, K. Kono, and A. Takamatsu, Japanese Patent 13,593, 1975.

${ }^{j}$ Strain 69895 coproduces the macrolide antibiotic oleandomycin. 
from those listed in Table 8. The identification at the species level and the taxonomic relationships of these strains will have to await studies involving their direct comparison with type and/or neotype strains of closely related nomenspecies.

\section{ACKNOWLEDGMENTS}

J. D. Skarbek gratefully acknowledges Public Health Service Graduate Fellowships from the National Institute of General Medical Science (no. 5-F01-GM-43,302) for the years 1969 to 1973.

The authors thank J. D. Mauseth and the Department of Botany, The University of Washington, Seattle, Wash., for electron micrographs and photomicrographs; E. B. Shirling, Ohio Wesleyan University, Delaware, Ohio, for assistance in acquisition of strains of Actinomyces nigrificans, A. atroolivaceus, $A$. globisporus subsp. flavofuscus, and $A$. variabilis from G. F. Gause; K. P. Munnelly and J. B. Routien, Pfizer, Inc., Groton, Conn., for a reference sample of mithramycin and for the mithramycin-producing strains of Streptomyces argillaceus and S. plicatus, respectively; Takeda Chemical Industries, Osaka, Japan, for approval of release of a culture of S. griseus no. 7 from the American Type Culture Collection; R. J. Hosley, Eli Lilly and Co., Indianapolis, Ind., for strain information and a culture of $S$. lavendulae M5-18903; J. A. Bush, Bristol Laboratories, Syracuse, N. Y. for cultures of strains C-1228 and C-14795; W. E. Grundy, Abbott Laboratories, North Chicago, Ill., for a culture of strain M-198; A. Seino, Kaken Chemical Co., Tokyo, Japan, for a culture of strain KCC S-1081; and T. Okuda, Tanabe Seiyaku Co., Saitama, Japan, for information on this strain; F. Parenti, Gruppo Lepetit, Milan, Italy, for a culture of strain L.A. 7017; Y. K. Sawa, Shionogi Research Laboratory, Osaka, Japan, for taxonomic information regarding S. griseus SK-229; and Drug Research and Development Chemotherapy, National Cancer Institute, for reference samples of olivomycin $\mathrm{A}$ and chromomycins $\mathbf{A}_{2}$ and $\mathbf{A}_{3}$.

\section{REPRINT REQUESTS}

Address reprint requests to: Dr. Jerry D. Skarbek, School of Pharmacy, University of Maryland, 636 West Lombard St., Baltimore, MD 21201.

\section{LITERATURE CITED}

1. Berlin, Y. A., O. A. Kiseleva, M. N. Kolosov, M. M. Shemyakin, V. S. Soifer, I. V. Vasina, I. V. Yartseva, and V. D. Kuznetsov. 1968. Aureolic acid group of antitumor antibiotics. Nature (London) 218:193-194.

2. Bringi, N. V., V. V. Bhatt, and M. J. Thirumalachar. 1960. An antibiotic related to aburamycin. Hind. Antibiot. Bull. 2:120-122.

3. Gause, G. F., R. S. Ukholina, and M. A. Sveshnikova. 1962. Olivomycin, a new antibiotic produced by Streptomyces olivoreticuli. Antibiotiki (Moscow) 7:34-38.

4. Gause, G. F., T. S. Maksimova, R. S. Ukholina, M. G. Brazhnikova, and E. B. Kruglyak. 1967. Act. atroolivaceus, a new mithramycin-producing ( $s i c$ ) organism. Antibiotiki (Moscow) 12:1059-1061.

5. Gottlieb, D., and E. B. Shirling. 1970. An analysis of species groups among Streptomyces, p. 67-77. In $\mathrm{H}$. Prauser (ed.), The Actinomycetales, VEB Gustav Fischer, Jena.

6. Gyllenberg, H. G., and M. Thelestam. 1967. Significance of polyene compounds as taxonomic criteria in streptomycetes. Ann. Med. Exp. Biol. Fenn. 45:127-130.

7. Higashide, E., T. Hasegawa, M. Shibata, K. Mizuno, M. Imanishi, and A. Miyake. 1965. Studies on streptomycetes. Simultaneous production of oleandomycin and chromomycins by Streptomyces olivochromogenes no. 69895. J. Antibiot. Ser. A 18:26-37.

8. Illarionova, R. P., D. E. Dykhovichnaya, and B. N. Bondarenko. 1970. pH chromatography on paper used in a determination of dissociation constants for antibiotics of the olivomycin-mithramycin group. Antibiotiki (Moscow) 15:415-418.

9. Kelly, D. L., and D. B. Judd. 1955. The ISCC-NBS method of designating colors and a dictionary of color names. U. S. Department of Commerce Circular 553. U. S. Government Printing Office, Washington, D. C.

10. Lapage, S. P., P. H. A. Sneath, E. F. Lessel, V. B. D. Skerman, H. P. R. Seeliger, and W. A. Clark (ed.). 1975. International code of nomenclature of bacteria and statutes of the International Committee on Systematic Bacteriology and statutes of the Bacteriology Section of the International Association of Microbiological Societies. American Society for Microbiology, Washington, D. C.

11. Liang, S. F., K. P. Chu, C. M. Yue, W. C. Pan, and P. C. Chen. 1974. Studies on the antitumor antibiotic B599-III: the biological properties of Streptomyces strain B-599. Acta Microbiol. Sin. 14:157-160.

12. Liu, S. S., H. L. Chang, Y. F. Ye, S. H. Hsu, and T. Y. Chang. 1974. Antitumor antibiotic B-599-III. II. Isolation and identification of chromomycin $\mathrm{A}_{3}$. Wei Sheng Wu Hsueh Pao 14:164-171.

13. Nishimura, H., T. Kimura, K. Tawara, K. Sasaki, K. Nakajima, N. Shimaoka, S. Okamoto, M. Shimohira, and J. Isono. 1957. Aburamycin, a new antibiotic. J. Antibiot. Ser. A 10:205-212.

14. Okanishi, M., H. Akagawa, and H. Umezawa. 1972. An evaluation of taxonomic criteria in streptomycetes on the basis of deoxyribonucleic acid homology. J. Gen. Microbiol. 72:49-58.

15. Oki, T., Y. Matsuzawa, K. Numata, and A. Takamatsu. 1973. SR1768A, an antitumor antibiotic closely related to chromomycin. J. Antibiot. Ser. A 26:701-704.

16. Pridham, T. G. 1970. New names and new combinations in the order Actinomycetales Buchanan 1917. Technical Bulletin No. 1424, Agricultural Research Service, U.S. Department of Agriculture. Superintendent of Documents, Washington, D. C.

17. Rudaya, S. M., E. M. Singal, S. A. Iliinskaya, and N. K. Solovieva. 1971. Act. olivovariabilis sp. nov., an organism producing variamycin, a new antitumor antibiotic. Antibiotiki (Moscow) 16:969-976.

18. Schmitz, H., B. Heinemann, J. Lein, and I. R. Hooper. 1960. NSC A-649, an antitumor antibiotic. Antibiot. Chemother. (Washington, D. C.) 10:740-746.

19. Sensi, P., A. M. Greco, and H. Pagani. 1958. Isolation and properties of a new antibiotic, L. A. 7017. Antibiot. Chemother. (Washington, D. C.) 8:241-244.

20. Shirling, E. B., and D. Gottlieb. 1966. Methods for characterization of Streptomyces species. Int. J. Syst. Bacteriol. 16:313-340.

21. Shirling, E. B., and D. Gottlieb. 1968. Cooperative description of type cultures of Streptomyces. III. Additional species descriptions from first and second studies. Int. J. Syst. Bacteriol. 18:279-392.

22. Shirling, E. B., and D. Gottlieb. 1972. Cooperative description of type strains of Streptomyces. V. Additional descriptions. Int. J. Syst. Bacteriol. 22:265-394.

23. Skarbek, J. D., and L. R. Brady. 1975. Isolation of chromomycin $\mathrm{A}_{3}$ from a new subspecies of Streptomyces. Lloydia 38:369-377.

24. Skarbek, J. D., and L. R. Brady. 1978. Streptomyces cavourensis sp. nov. (nom. rev.) and Streptomyces ca. vourensis subsp. washingtonensis subsp. nov., a chromomycin-producing subspecies. Int. J. Syst. Bacteriol. 28:45-53.

25. Slavik, M., and S. K. Carter. 1975. Chromomycin $A_{3}$, mithramycin, and olivomycin: antitumor antibiotics of 
related structure, p. 1-30. In S. Garattini, A. Goldin, F. Hawking, and I. J. Kopin (ed.), Advances in pharmacology and chemotherapy. Academic Press Inc., New York.

26. Thirumalachar, M. J., P. W. Rahalkar, P. V. Deshmukh, and R. S. Sukapure. 1965. Production of aburamycin by Chainia minutisclerotica, a new species of actinomycete. Hind. Antibiot. Bull. 8:6-9.

27. Tresner, H. D., J. A. Hayes, and E. J. Backus. 1968. Differential tolerance of streptomycetes to sodium chloride as a taxonomic aid. Appl. Microbiol. 16:1134-1136.

28. Ukholina, R. S., E. B. Kruglyak, V. N. Borisova, I. N. Kovsharova, and V. V. Proshlyakova. 1965. Pro- duction of antibiotics closely related to olivomycin by various actinomycete species. Microbiology (USSR) 34:118-126.

29. Vinogradova, K. A., N. T. Dat, and A. B. Silaev. 1975. Intraspecific variability of Actinomyces aburaviensis var. verrucosus. Biol. Nauki (Moscow) 18:89-93.

30. Vinogradova, K. A., N. T. Dat, and A. B. Silaev. 1975. New producer of chromomycin, Actinomyces aburaviensis var. verrucosus. Biol. Nauki (Moscow) 18:95-101.

31. Waksman, S. A. 1961. The actinomycetes, vol. 2. Classification, identification and descriptions of genera and species. Williams and Wilkins Co., Baltimore. 